\title{
Pengaruh Blended Learning Dan Portal Rumah Belajar Terhadap Motivasi Dan Hasil Belajar Siswa
}

\author{
Waluyo Iskak
}

SD Negeri 380 Gresik

waluyoiskak19@gmail.com

\section{Article History}

accepted 01/12/2020

\begin{abstract}
The Effect of Blended Learning and Home Learning Portal on Student Motivation and Learning Outcomes. This study aims to: 1) determine the differences in learning motivation and learning outcomes between students who are taught blended learning compared to students who are taught conventional learning, 2) determine the increase in learning motivation and student learning outcomes due to the application of blended learning. This type of research is experimental. The study population was 24 class students of UPT SD Negeri 380 Gresik. Data collection techniques used interviews and written test questionnaires. The data obtained were verified, validated and analyzed. The results are as follows. 1) There is a difference in learning motivation between students who are taught blended learning compared to conventional learning 2) There is an increase in student learning motivation due to the application of blended learning with an increase in average value of 13.55 and there is an increase in student learning outcomes with an increase in average value of 38,23.
\end{abstract}

Keywords: blended learning, portal, motivation, learning

\begin{abstract}
Abstrak
Penelitian ini bertujuan untuk: 1) mengetahui perbedaan motivasi belajar dan hasil belajar antara siswa yang diajarkan pembelajaran blended learning dibanding siswa yang diajarkan pembelajaran konvensional, 2) mengetahui peningkatan motivasi belajar dan hasil belajar siswa akibat penerapan pembelajaran blended learning. Jenis penelitian ini adalah experiment. Populasi penelitian adalah siswa kelas sebanyak 24 siswa UPT SD Negeri 380 Gresik. Teknik pengumpulan data menggunakan wawancara dan angket tes tulis. Data yang diperoleh diverifikasi, divalidasi dan dianalisis. Hasilnya sebagai berikut. 1) Ada perbedaan motivasi belajar antara siswa yang diajar pembelajaran blended learning dibandingkan pembelajaran konvensional 2) Ada peningkatan motivasi belajar siswa akibat penerapan pembelajaran blended learning dengan nilai rata-rata peningkatan 13,55 dan ada peningkatan hasil belajar siswa dengan nilai rata-rata peningkatan 38,23 .
\end{abstract}

Kata kunci: blended learning, portal, motivasi, belajar

Social, Humanities, and Education Studies (SHEs): Conference Series https://jurnal.uns.ac.id/shes

p-ISSN 2620-9284

e-ISSN 2620-9292 


\section{PENDAHULUAN}

Istilah blended learning pada awalnya digunakan untuk menggambarkan mata pelajaran yang mencoba menggabungkan pembelajaran tatap muka dengan pembelajaran online. Selain blended learning ada istilah lain yang sering digunakan di antaranya blended learning dan hybrid learning. Istilah yang disebutkan tadi mengandung arti yang sama yaitu perpaduan, percampuran atau kombinasi pembelajaran.

Blended learning sebagai kombinasi karakteristik pembelajaran tradisional dan lingkungan pembelajaran elektronik atau Blended learning. menggabungkan aspek Blended learning (format elektronik) seperti pembelajaran berbasis web, streaming video, komunikasi audio synchronous dan asynchronous dengan pembelajaran tradisional "tatap muka".

Proses penyelenggaraan e-learning, dibutuhkan sebuah Learning Management System (LMS), yang berfungsi untuk mengatur tata laksana penyelenggaraan pembelajaran di dalam model e-learning. Sering juga LMS dikenal sebagai CMS (Course Management System), umunya CMS dibangun berbasis web, yang akan berjalan pada sebuah web server dan dapat diakses oleh pesertanya melalui web browser (web client). Server biasanya ditempatkan di universitas/sekolah atau lembaga lainnya, yang dapat diakses darimanapun oleh pesertanya, dengan memanfaatkan koneksi internet.

Motivasi adalah proses internal yang mengaktifkan, menuntun, dan mempertahankan perilaku dari waktu ke waktu. Ada banyak jenis, intensitas, tujuan, dan arah motivasi yang berbeda-beda. Motivasi untuk belajar sangat berperan penting bagi siswa dan guru.

Pembelajaran mandiri, merujuk pada pembelajaran yang berasal dari pemikiran dan perilaku yang dihasilkan sendiri oleh siswa yang secara sistematis diarahkan ke sasaran pembelajaran mereka. Motivasi intrinsik siswa pada umumnya menurun dari sekolah dasar tahun-tahun pertama hingga sekolah menengah. Karena alasan ini sekolah menerapkan berbagai insentif ekstrinsik (extrinsic incentive), yaitu imbalan untuk pembelajaran yang tidak melekat dalam bahan yang sedang dipelajari . Imbalan ekstrinsik dapat berkisar dari pujian, nilai, penghargaan, hingga hadiah atau imbalan lain. Fenomena motivasi intrinsik mencerminkan kecenderungan utama manusia untuk terlibat dalam kegiatan yang menarik perhatian mereka untuk belajar, mengembangkan dan memperluas kapasitas mereka. Motivasi intrinsik yang terkandung setiap kali orang berperilaku untuk kepuasan yang melekat dalam perilaku itu sendiri (Sansone, Harackiewicz, 2000:16)

Hasil belajar merupakan kemampuan yang diperoleh individu setelah proses belajar berlangsung, yang dapat memberikan perubahan tingkah laku baik pengetahuan, pemahaman, sikap dan keterampilan siswa sehingga menjadi lebih baik dari sebelumnya. Sebagaimana yang dikemukakan Hilgard yang dikutip oleh Sanjaya, (2010:228-229)

Menurut Hilgard, belajar itu adalah proses perubahan melalui kegiatan atau prosedur latihan baik latihan di dalam laboratorium maupun dalam lingkungan alamiah. Pendapat tersebut didukung oleh Sanjaya (2010:229) bahwa hasil belajar adalah suatu proses aktivitas mental seseorang dalam berinteraksi dengan lingkungannya sehingga menghasilkan perubahan tingkah laku yang bersifat positif baik perubahan dalam aspek pengetahuan, sikap, maupun psikomotor. Dikatakan positif, oleh karena perubahan perilaku itu bersifat adanya penambahan dari perilaku sebelumnya yang cenderung menetap (tahan lama dan tidak mudah dilupakan).

Berdasarkan pengertian di atas maka dapat disintesiskan bahwa hasil belajar adalah suatu penilaian akhir dari proses dan pengenalan yang telah dilakukan 
berulang-ulang serta akan tersimpan dalam jangka waktu lama atau bahkan tidak akan hilang selama-lamanya karena hasilbelajar turut serta dalam membentuk pribadi individu yang selalu ingin mencapai hasil yang lebih baik lagi sehingga akan merubah cara berpikir serta menghasilkan perilaku kerja yang lebih baik.

Penelitian yang telah dilakukan oleh Muhamad Ali, Istanto WD, Sigit Y, Muhamad Munir (2011) dari FT UNY dengan judul " Studi Pemanfaatan e-Learning sebagai Media Pembelajaran Guru dan Siswa SMK di Yogyakarta" dari hasil kesimpulan dikatakan bahwa pembelajaran e-learning memberikan pengaruh yang cukup signifikan pada motivasi belajar guru dan siswa, tetapi untuk hasil belajar dan waktu menyelesaikan pelajaran pengaruhnya belum signifikan.

Berdasarkan kajian teori dan hasil-hasil penelitian yang relevan, maka tujuan penelitian ini adalah: (1) mengetahui perbedaan motivasi belajar antara siswa yang diajarkan pembelajaran blended learning dibanding siswa yang diajarkan pembelajaran konvensional; (2) mengetahui perbedaan hasil belajar antara siswa yang diajarkan pembelajaran blended learning dibanding siswa yang diajarkan pembelajaran konvensional; (3) mengetahui peningkatan motivasi belajar siswa akibat penerapan pembelajaran blended learning; (4) mengetahui peningkatan hasil belajar siswa akibat penerapan pembelajaran blended learning. berikut.

Secara umum kerangka pikir dalam penelitian ini dapat diilustrasikan sebagai

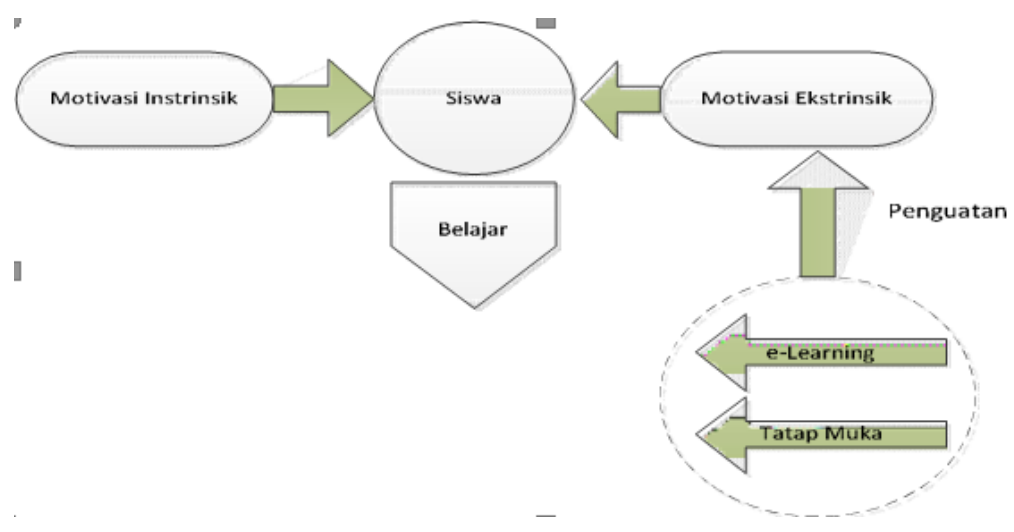

\section{Gambar 1.Kerangka Pikir}

Pendidik harus membuka akses pembelajaran abad 21 yang mendukung kegiatan di masa pandemi yaitu fortal Rumah Belajar https://belajar.kemdikbud.go.id/ yang bisa dimanfaatkan secara gratis. Rumah belajar adalah portal pembelajaran yang menyediakan bahan belajar serta fasilitas komunikasi yang mendukukung interaksi antar warga sekolah PAUD, SD, SMP, dan SMA/SMK sederajat sebagai inovasi pembelajaran di era industri 4.0 dan masa pandemi. Melalui rumah belajar, kita dapat belajar di mana saja, kapan saja dengan siapa saja dengan berbagai fitur utama dan pendukung rumah belajar.

Fitur utama rumah belajar yaitu Sumber Belajar yang menyajikan materi ajar bagi peserta didikdan pendidik sesuai kurikulum. Materi pembelajaran disajikan dalam bentuk multimedia interaktif (teks, gambar, audio, video, animasi, simulasi dalam bentuk latihan, kuis, dan tes) yang menarik. Konten pembelajaran ini sangat tepat digunakan pada masa pandemi karena didalamnya terdapat berbagai reperensi yang mendukung kegiatan belajar dari rumah (BDR).

Selanjutnya fitur Kelas Digital yang dikembangkan khusus untuk memfasilitasi proses pembelajaran virtual (tatap maya) atau tanpa tatap muka antara 
pendidik dan peserta didik seperti halnya LMS (Learning Management System). Penyelenggara kelas digital adalah sekolah melalui kepala sekolah untuk membuka kelas, mengatur, merencanakan, dan melaksanakan pembelajaran. Dengan fitur ini, pendidik dapat memberikan bahan ajar yang dapat diakses dan dibagikan oleh peserta didik dalam bentuk digital kapan saja dan di mana saja.

Kemudian fitur Bank Soal yang dapat membantu peserta didik dan pendidik memaksimalkan pembelajaran, dalam hal ini mengikuti perkembangan hasil belajar peserta didik. Fitur Bank Soal dikembangkan sebagai wadah bagi peserta didik untuk membuat soal latihan, ulangan, dan ujian. Fitur ini juga sebagai alat Instrumen evaluasi pendidik untuk menilai sejauh mana proses pembelajaran tersampaikan kepada peserta didik.

Fitur terakhir adalah Laboratorium Maya yang memiliki kemampuan untuk melakukan modeling peralatan komputer secara matematis yang disajikan melalui sebuah simulasi. Laboratorium ini merupakan bentuk praktikum yang digunakan dalam aktivitas pembelajaran ataupun penelitian secara ilmiah guna menekankan sebuah konsep tertentu. Fitur ini diperuntukkan untuk peserta didik yang duduk dibangku SMP, SMA dan SMK sederajat terutama yang belum memiliki laboratorium secara fisik.

Selain fitur utama, dalam rumah belajar ada pula beberapa fitur pendukung yaitu Peta Budaya, Buku Sekolah Elektronik, Wahana Jelajah Angkasa, Karya Bahasa dan Sastra, Pengembangan Keprofesian Berkelanjutan dan yang terbaru Edugame. Konten- konten dan media pembelajaran yang tersedia tersebut juga dapat dimanfaatkan oleh pendidik, peserta didik, dan masyarakat dalam belajar.

Penggunaan fitur Peta Budaya untuk memberi kemudahan peserta didik dalam mempelajari budaya Indonesia dengan mudah dan menyenangkan. Peserta didik tinggal klik salah satu dari provinsi dari gambar peta yang disajikan pada portal Rumah Belajar yang inovatif dan variatif. Dengan adanya peta budaya ini, peserta didik akan belajar dengan semangat, lebih rajin, dan juga selesai tepat waktu dalam mengumpulkan tugas.

Fitur Buku Sekolah Elektronik (BSE) merupakan sumber rujukan mencari materi pembelajaran untuk menambah referensi pendidik dalam pembelajaran. BSE tersedia berbagai macam buku pelajaran dari semua jenjang baik SD, SMP, SMA dan SMK yang dapat pendidik unduh secara gratis. Sehingga pendidik takkan kesulitan mengikuti perkembangan kurikulum yang sesuai kondisi sekolah masing- masing.

Selanjutnya fitur Wahana Jelajah Angkasa yang digunakan peserta didik dan pendidik melakukan jelajah luar angkasa secara virtual (maya) dengan penampakan 3 dimensi (3D). Keinginan belajar tentang astronomi sering kali terbentur akses dan fasilitas, akan tetapi semua terwujud dari kerja sama Kemdikbud dengan Microsoft Indonesia. Dalam penggunaan Wahana Jelajah Angkasa, pendidik akan sangat membantu dalam memvisualisasikan benda-benda luar angkasa kepada peserta didik baik di dalam kelas.

Fitur Karya Bahasa dan Sastra memberikan banyak pilihan buku cerita yang disesuaikan dengan kebutuhan dan minat baca anak-anak. Fitur ini terdiri atas 3 konten yaitu prosa, puisi dan referensi. Dalam konten Prosa terdapat banyak judul buku cerita rakyat dari seluruh Indonesia yang dapat menambah pengetahuan dan wawasan dan menumbuhkan semangat nasionalisme serta cinta tanah air. Kemudian konten Puisi terdapat buku- buku puisi dan juga antalogi puisi yang sangat menarik untuk dibaca. Fitur ini juga dapat menjadi sumber referensi untuk kegiatan literasi baca tulis di sekolah maupun di rumah secara online dan gratis.

Pengembangan Keprofesian Berkelanjutan (PKB) adalah sebuah fitur yang dapat dimanfaatkan untuk meningkatkan kompetensi pendidik, terutama yang berkaitan dengan pengintegrasian TIK dalam pembelajaran. Fitur ini menyediakan 
informasi tentang pelatihan, seminar, dan perlombaan yang berkaitan dengan pemanfaatan TIK dalam pembelajaran. Sehingga pendidik memperoleh kesempatan untuk meningkatkan literasi TIK secara gratis tanpa harus meninggalkan kewajibannya sebagai pendidik di sekolah.

Fitur Terbaru Edugame, sebuah media pembelajaran berbasis game edukasi bermain sambil belajar untuk mendukung pembelajaran di kelas maupun di luar kelas. Hal ini juga menjadi salah satu alternatif agar peserta didik tidak mudah bosan saat belajar. Fitur ini menyediakan beragam games interaksi yang dapat dimanfaatkan secara mandiri atau dengan bimbingan pendidik dan orang tua. Game ini sangat menarik untuk dimainkan sebagai pembelajaran peserta didik, dan dikemas dengan visual yang menarik untuk mengasah kreatifitas anak.

Semua fitur utama dan pendukung Rumah Belajar diatas dapat digunakan pendidik dalam menghadapi wabah covid-19 yang tak kunjung reda. sehingga pembelajaran tetap berjalan sesuai kurikulum yang ada dan protokol kesehatan tetap terkontrol dengan baik. Selain menghindari terpapar covid-19, pendidik secara tidak langsung mengajarkan kepada peserta didik untuk beradaptasi kebiasaan hidup baru bersama portal Rumah Belajar.

Pendidik berharap agar semua insan yang berkepentingan dengan dunia pendidikan agar menggunakan laman Rumah Belajar https://belajar.kemdikbud.go.id/ dimasa pandemi ini. Rumah belajar memberikan berbagai alternatif dalam menunjang proses pembelajaran dan yang paling di rekomendasikan karena tidak berbayar/ gratis. Dengan belajar dimana saja, kapan saja, dan bersama siapapun saja, kita akan merdeka belajarnya karena rumah belajar fortalnya dan akhirnya majulah Indonesia.

\section{METODE}

Populasi dalam penelitian ini adalah seluruh siswa kelas 4 sebanyak 24 orang dari UPT SD Negeri 380 Gresik. Teknik pengumpulan data dalam penelitian ini berupa wawancara, angket dan tes tertulis yang diberikan kepada siswa. Teknik analisis data dilakukan dengan langkah-langkah: diverifikasi dan divalidasi serta dianalisis.

\section{HASIL DAN PEMBAHASAN}

Berdasarkan hasil analisis bahwa terdapat perbedaan motivasi belajar antara siswa yang diajarkan pembelajaran blended learning dibandingkan siswa yang diajarkan pembelajaran konvensional. Rata-rata skor motivasi belajar yang diukur sebelum pembelajaran blended learning sebesar 83,97. Kemudian setelah diberi pembelajaran dengan memanfaatkan blended learning sebanyak lima kali pertemuan, motivasi belajar diukur lagi dan diperoleh rata-rata motivasi belajar 97,52 yang artinya ada peningkatan rata-rata sebesar 13,55 . Gambaran peningkatan rata-rata motivasi belajar disajikan pada Gambar berikut ini.

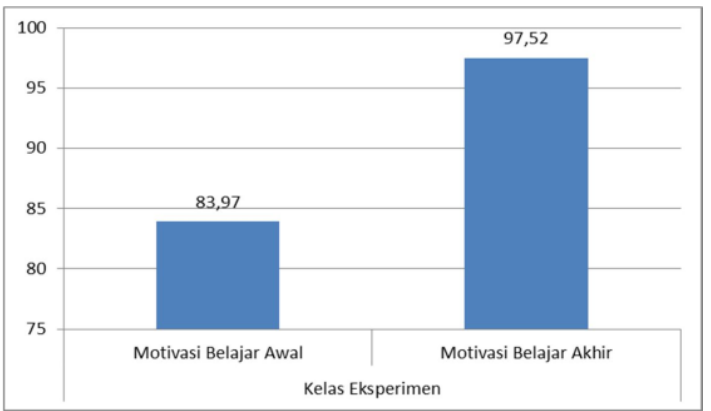

Gambar 2. Rata-Rata Motivasi Belajar Sebelum dan Sesudah Menggunakan Blended Learning dan Portal Rumah Belajar 
Rata-rata skor hasil belajar yang diukur sebelum pembelajaran blended learning sebesar 39,35. Kemudian setelah diberi pembelajaran dengan menerapkan blended learning, hasil belajar diukur lagi dan diperoleh rata-rata hasil belajar 77,58 yang artinya ada peningkatan hasil belajar rata-rata sebesar 38,23. Gambaran peningkatan rata-rata hasil belajar disajikan pada Gambar berikut ini.

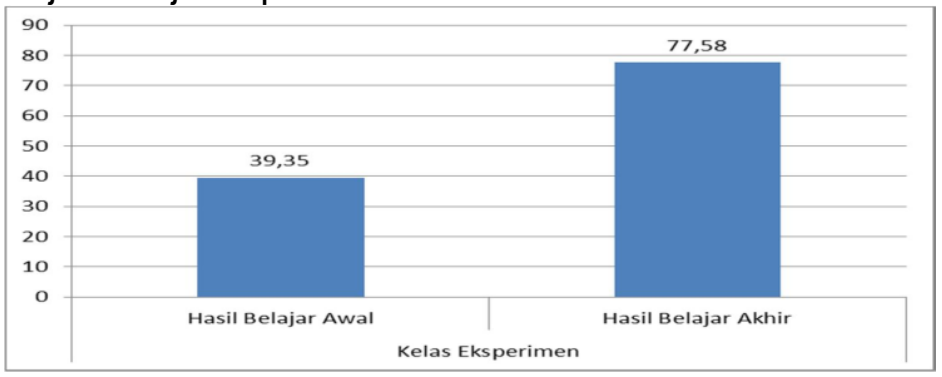

\section{Gambar 3. Rata-Rata Hasil Belajar Sebelum dan Sesudah Menggunakan Blended Learning dan Portal Rumah Belajar}

\section{SIMPULAN}

Berdasarkan hasil penelitian yang telah dikemukakan pada bab sebelumnya, dapat disimpulkan sebagai berikut: (1) terdapat perbedaan motivasi belajar antara siswa yang diajarkan pembelajaran blended learning dibandingkan siswa yang diajarkan pembelajaran konvensional; (2) terdapat perbedaan hasil belajar antara siswa yang diajarkan pembelajaran blended learning dibandingkan siswa yang diajarkan pembelajaran konvensional; (3) ada peningkatan motivasi belajar siswa akibat penerapan pembelajaran blended learning; (4) ada peningkatan hasil belajar siswa akibat penerapan pembelajaran blended learning.

Berdasarkan simpulan di atas, peneliti memberikan saran untuk berbagai pihak yang berkepentingan terhadap penelitian ini, yaitu: (1) para guru dapat menerapkan pembelajaran blended learning pada mata diklat yang di ampu karena terbukti terdapat perbedaan motivasi belajar dan hasil belajar antara siswa yang diajarkan pembelajaran blended learning dibandingkan siswa yang diajarkan pembelajaran konvensional; (2) guru dapat menerapkan pembelajaran blended learning pada mata pelajaran yang di ampu karena terbukti ada peningkatan motivasi belajar siswa dan peningkatan hasil belajar siswa.

\section{DAFTAR PUSTAKA}

Cepi Riyana. 2011. Teknologi informasi dan komunikasi dalam pembelajaran: Blended learning. Artikel tik, 21-24. 13 Oktober 2011, dari http://kurtek.upi.edu/tik/content/blend ed.pdf.

Depdiknas. 2005. Undang-Undang RI. Nomor 14 Tahun 2005 tentang Guru dan Dosen.

Depdiknas. 2007. Peraturan Menteri Pendidikan Nasional RI. Nomor 16 Tahun 2007 tentang Standar Kualifikasi Akademik dan Kompetensi Guru.

Https://belajar.kemdikbud.go.id/

Sansone, C., Judith, M., \& Harackiewicz. (2000). Intrinsic and extrinsic motivation: The search for optimal motivation and performance. San Diego: Academic Press.

Wasis Dwiyogo. 8 Mei 2012. Blended Learning. Pembelajaran berbasis blended learning. 
13 Mei 2012 dari http : //id.wikibooks.org /wiki / Pembelajaran Berbasis Blended_Lear ning.

Wikipedia. (10 Mei 2012). program pembelajaran elektronik. Learning management system. 13 Mei 2012 dari http:// http://id.wikipedia.org/ wiki/ Learning_ Management_System. 